\title{
The Morphostructural, Compositional, and Electrochemical Characterization of Electrodeposited Nanolayers on a New Ti-15Ta-5Zr Alloy
}

\author{
Cora Vasilescu, Silviu Iulian Drob, Petre Osiceanu, Mihai Anastasescu, \\ Jose M. Calderon-Moreno, Paula Drob, and Ecaterina Vasilescu \\ Romanian Academy, Institute of Physical Chemistry "Ilie Murgulescu", Splaiul Independentei 202, 060021 Bucharest, Romania \\ Correspondence should be addressed to Silviu Iulian Drob; sidrob@chimfiz.icf.ro
}

Received 7 February 2014; Accepted 21 March 2014; Published 30 April 2014

Academic Editor: Fathallah Karimzadeh

Copyright (c) 2014 Cora Vasilescu et al. This is an open access article distributed under the Creative Commons Attribution License, which permits unrestricted use, distribution, and reproduction in any medium, provided the original work is properly cited.

\begin{abstract}
A porous, homogeneous, phosphorous-enriched oxide nanolayer was realized on the new Ti-15Ta-5Zr alloy surface by the anodic galvanostatic electrodeposition in phosphoric acid solution. This nanolayer contains $\mathrm{TiO}_{2}, \mathrm{ZrO}_{2}$ oxides, tantalum suboxides, and $\mathrm{PO}_{4}{ }^{3-}$ ions incorporated in the time of the electrodeposition process and has a thickness of $15.5 \mathrm{~nm}$ (X-ray photoelectron spectroscopy data). Atomic force microscopy determined a homogeneous roughness. Scanning electron microscopy evinced a porous microstructure that can stimulate the growth of the bone tissue into pores. The presence of the $\mathrm{PO}_{4}{ }^{3-}$ anions promotes the electrostatic bonds between the nanolayer and different species from the biofluid, namely, osteoinduction. The anodic oxidation nanolayer improved all electrochemical and corrosion parameters conferring superior protection to the substrate by its higher resistance to the ion migration. Impedance spectra showed that the electrodeposited nanolayer is formed by an inner, dense, barrier layer and an outer porous layer. The nanolayer thickened in time, namely, is bioactive. The oxidized nanolayer is able to protect the alloy from ion release, to assure long-term corrosion resistance, to minimize adverse reactions, to increase alloy bioactivity, to stimulate cell growth, and to favor osseointegration.
\end{abstract}

\section{Introduction}

Titanium and its alloys represent a class of materials with large applications both in industry (aerospace, marine, and chemical) and medicine due to their very high corrosion resistance. In medicine, Ti and its alloys used to bone reconstructions have accomplished numerous criteria for dental and orthopedic implants: biocompatibility [1], nonallergic reactions, inertness to the human body fluids, rigidity, low density and elasticity (closed to the bone) [2], good mechanical properties, wear and fatigue resistance, bone bonding ability, and so forth, $[3,4]$. The anticorrosive resistance is the most decisive property for the biocompatibility of metallic materials because it reduces very much the ion release into the biofluid; $\mathrm{Ti}$ and its alloys realize this need as result of the existence of a very stable oxide, passive film on their surfaces, but this film can be altered by the bone movement that can produce wear corrosion [5]. A method to avoid these shortcomings is the thickening of this passive film by different techniques. In the same time, it is necessary to assure the very good attachment of the bone cells with the metallic implant by the modification of the surface topography, roughness, and so on, to increase the binding and fixation between them.

An efficient, cheap, easy method to thicken the protective oxide films is the electrochemical anodization. This method is more convenient than other methods as plasma spray, solgel, chemical or physical vapor deposition, ion implantation, and so forth, because, in addition, the adherence of the formed oxide layer is very high, and its thickness can be controlled by the electrodeposition parameters, can be applied on the complex surfaces, can incorporate ions (as phosphates) and species from the deposition solutions which can reinforce its protective capacity, and can promote the formation of phosphate, the main inorganic component of the bone, therefore the bioactivity of the metallic implant, and implicitly its direct contact with the bone. The electrochemical anodization can be performed by potentiostatic and 
galvanostatic polarization. The potentiostatic anodization [614] uses expensive equipment, potentiostat, and under a high anodic voltage, in different acidic or neutral solution, the oxide layer grows. The galvanostatic anodization [4, 5, 15-19] produces by a versatile way a uniform, relative high porous, rough oxide layer that contains ions, and elements from the electrodeposition solution.

We obtained a porous, homogeneous nanolayer on the new Ti-15Ta-5Zr alloy surface by the anodic galvanostatic electrodeposition in phosphoric acid $\mathrm{H}_{3} \mathrm{PO}_{4}$ solution; varying different parameters as solution concentration, current density, deposition time, the most favorable nanolayer with the best rough (by Atomic Force Microscopy (AFM)), morphology (by Scanning Electron Microscopy (SEM)), and composition and thickness (by X-ray Photoelectron Spectroscopy (XPS)) was selected and its electrochemical behavior and corrosion resistance in Ringer physiological solutions of different $\mathrm{pH}$ values, simulating the real functional conditions of an implant, were determined by the potentiodynamic cyclic and linear polarization and electrochemical impedance spectroscopy (EIS). Also, the long-term behavior of the obtained nanolayer was studied from the monitoring of the open circuit potentials and corresponding open circuit potential gradients in Ringer solutions.

\section{Experimental Details}

The new Ti-15Ta-5Zr alloy was synthesized by two successive vacuum melting in semilevitation furnace with cold crucible. The raw materials had high purity and the composition of the as-cast ingots was (\%wt.): $0.011 \% \mathrm{H} ; 0.02 \% \mathrm{~N} ; 0.12 \% \mathrm{O} ; 0.015 \%$ Si; $0.0074 \%$ Zn; $0.0035 \%$ Nb; $0.0052 \%$ Sn; $14.26 \%$ Ta; $4.771 \%$ Zr; balance Ti.

2.1. Electrodeposition of the Nanolayers. Before the electrodeposition, the cylindrical electrodes were progressively ground with emery paper (from 400 till 2000 mesh) and mirrorpolished with aluminum paste. Then, the samples were ultrasonically degreased in acetone and water for every $15 \mathrm{~min}$ and dried in air. The anodic galvanostatic electrodeposition was applied by a high power current source (Matrix, China) in $\mathrm{H}_{3} \mathrm{PO}_{4}$ solutions of different concentrations, $0.5 \mathrm{M}-1.5 \mathrm{M}$, at anodic current densities varying between $5 \mathrm{~mA} / \mathrm{cm}^{2}$ and $15 \mathrm{~mA} / \mathrm{cm}^{2}$, for various time periods from $15 \mathrm{~min}$ till $90 \mathrm{~min}$. Optical observations showed that at low acid concentration, current density, and time, the obtained nanolayer did not covered the entire surface. In proportion as the values of these three electrodeposition parameters (concentration, current density, and time) increased, the colored thin layers from gold to blue could be observed; these nanolayers were characterized by different techniques and the nanolayer with the most favorable microstructural properties was selected.

2.2. Characterization of the Electrodeposited Nanolayers. The composition and thickness of the electrodeposited nanolayer were analyzed by X-ray Photoelectron Spectroscopy (XPS), its topography and roughness by Atomic Force Microscopy
(AFM), and its microstructure, morphology, and porosity by Scanning Electron Microscopy (SEM).

2.2.1. X-Ray Photoelectron Spectroscopy. XPS was applied by Quantera SXM equipment at a pressure of $1.33 \times 10^{-7} \mathrm{~Pa}$; the $\mathrm{X}$-ray source was $\mathrm{AlK}_{\alpha}$ radiation $(1486.6 \mathrm{eV}$ monochromatized) by a full width at half maximum (FWHM) of Au4f line. The spectra were calibrated with $\mathrm{C}$ 1s line (binding energy $\mathrm{BE}=284.8 \mathrm{eV}$ ) of the adsorbed hydrocarbon on the sample surface. A dual beam neutralizing procedure ( $\mathrm{e}^{-}$and $\mathrm{Ar}^{+}$ion beams) has been used to compensate the charging effect in the insulating samples. The errors in the quantitative analysis were estimated in the range of $\pm 10 \%$, and the accuracy for the BEs was $\pm 0.2 \mathrm{eV}$. The thickness of the electrodeposited layer was determined by XPS depth profiling, layer by layer experiment under $1 \mathrm{keV}$ and $3 \times 3 \mathrm{~mm}$ scanning area, $45^{\circ}$ incident angle, and $100 \mu \mathrm{m}$ spot size. These parameters were used to minimize the reduction effect of the ion beam on the surface oxides.

2.2.2. Atomic Force Microscopy. AFM measurements were carried out in the noncontact mode with XE-100 apparatus equipped with flexure-grinded, cross-talked eliminated scanners, using sharp tips (radius $<7 \mathrm{~nm}$ ) of about $225 \mu \mathrm{m}$ length, $38 \mu \mathrm{m}$ width, and $48 \mathrm{~N} / \mathrm{m}$ spring constant at ca. $190 \mathrm{kHz}$ resonance frequency. The topographical $2 \mathrm{D}$ and $3 \mathrm{D}$ AFM images were taken over an area of $2 \times 2 \mu \mathrm{m}$ and were used to calculate root mean square (RMS) and average surface (Rav) roughness.

2.2.3. Scanning Electron Microscopy. SEM micrographs were obtained with FEI Quanta 2DFEG Dual Beam system operating in secondary (SE) and back-scattered (BSE) detector at an accelerating voltage of $5 \mathrm{kV}$.

2.3. Electrochemical Methods. Electrochemical and corrosion behavior of the most favorable electrodeposited nanolayer were examined by cyclic potentiodynamic and linear polarization and electrochemical impedance spectroscopy (EIS) [20-26].

Cyclic potentiodynamic polarization furnished the cyclic voltammograms and the main electrochemical parameters: corrosion potential, $E_{\text {corr }}$; passivation potential, $E_{p}$; tendency to passivation, $\left|E_{\text {corr }}-E_{p}\right|$; passive potential range, $\Delta E_{p}$; passive current density, $i_{p}$. The cyclic potentiodynamic polarization curves were registered from about $-800 \mathrm{mV}$ till $+2000 \mathrm{mV}$ (versus SCE) with a scan rate of $1 \mathrm{mv} / \mathrm{s}$, using Voltalab 80 equipment.

Potentiodynamic linear polarization was performed for $\pm 50 \mathrm{mV}$ around the open circuit potential at a scan rate of $0.5 \mathrm{mV} / \mathrm{s}$ using the same Voltalab 80 equipment. VoltaMaster 4 program adjusted Tafel curves and directly supplied the values of corrosion current density, $i_{\text {corr }}$; corrosion rate, $V_{\text {corr }}$; polarization resistance, $R_{p}$; the total quantity of ions released into solution was calculated [27].

EIS was applied at the open circuit potential with $5 \mathrm{mV}$ voltage amplitude in the frequency range from $10^{-1} \mathrm{~Hz}$ to $10^{5} \mathrm{~Hz}$ with 7 points per decade. The Voltalab 80 equipment 
and its VoltaMaster 4 program displayed Nyquist and Bode spectra. Zview program modeled the electric equivalent circuit.

The electrochemical behavior of the electrodeposited nanolayer on the Ti-15Ta-5Zr alloy surface in comparison with base alloy was studied in Ringer physiological solutions of different $\mathrm{pH}$ values (acid $\mathrm{pH}=3.54$, obtained by $\mathrm{HCl}$ addition; neutral $\mathrm{pH}=7.49$; alkaline $\mathrm{pH}=8.98$, obtained by $\mathrm{KOH}$ addition), simulating the real functional conditions of an implant. In case of surgery, the local acidification of the biofluid can appear due to the traumatisms [28]. In the distress periods of the human body (infections or inflammations), local alkalinity can form [29].

Ringer solution composition was (g/L): $\mathrm{NaCl}-6.8 ; \mathrm{KCl}-$ $0.4 ; \mathrm{CaCl}_{2}-0.2 ; \mathrm{MgSO}_{4} \cdot 7 \mathrm{H}_{2} \mathrm{O}-0.2048 ; \mathrm{NaH}_{2} \mathrm{PO}_{4} \cdot \mathrm{H}_{2} \mathrm{O}-$ $0.1438 ; \mathrm{NaHCO}_{3}-1.1$; glucose-1. Temperature was kept at $37^{\circ} \pm 1^{\circ} \mathrm{C}$.

The open circuit potentials $E_{\mathrm{oc}}$ of the bare and oxidized Ti-15Ta-5Zr alloy were monitored for 500 immersion hours in Ringer solutions using a performing Hewlett-Packard multimeter.

The open circuit potential gradients $\Delta E_{\mathrm{oc}}$ [27] which can develop along the implant surface due to the local nonuniformity of the physiological solution $\mathrm{pH}$ were calculated as:

$$
\begin{aligned}
& \Delta E_{\mathrm{oc} 1}(\mathrm{pH})=E_{\mathrm{oc}}^{\mathrm{pH}=3.54}-E_{\mathrm{oc}}^{\mathrm{pH}=7.49}, \\
& \Delta E_{\mathrm{oc} 2}(\mathrm{pH})=E_{\mathrm{oc}}^{\mathrm{pH}=3.54}-E_{\mathrm{oc}}^{\mathrm{pH}=8.98}, \\
& \Delta E_{\mathrm{oc} 3}(\mathrm{pH})=E_{\mathrm{oc}}^{\mathrm{pH}=7.49}-E_{\mathrm{oc}}^{\mathrm{pH}=8.98} .
\end{aligned}
$$

\section{Results and Discussion}

3.1. Composition and Thickness of the Electrodeposited Nanolayer. XPS analysis showed that the nanolayer obtained by the electrodeposition in $1.1 \mathrm{M} \mathrm{H}_{3} \mathrm{PO}_{4}$ solution at a current density of $12 \mathrm{~mA} / \mathrm{cm}^{2}$ for a period of $50 \mathrm{~min}$ had the most convenient composition, thickness and price. XPS survey spectrum (Figure 1) identified the main peaks of binding energies for Ti 2p, Ta 4f, $\mathrm{Zr} 3 \mathrm{~d}$ (the constituent elements of Ti-15Ta-5Zr alloy), and, in addition, $\mathrm{O}$ 1s and P 2p [30, 31] incorporated from the electrolyte.

High resolution XPS spectra (Figure 2) for the nanolayer electrodeposited at $12 \mathrm{~mA} / \mathrm{cm}^{2}$, in $1.1 \mathrm{M} \mathrm{H}_{3} \mathrm{PO}_{4}$ solution for 50 min indicated that the doublet of Ti 2p (Figure 2(a)) had a peak at a binding energy of $458.8 \mathrm{eV}$ that is specifically for $\mathrm{TiO}_{2}$ protective oxide [30-33]; the doublet of $\mathrm{P} 2 \mathrm{p}$ (Figure $2(\mathrm{~d})$ ) contains a peak at $133.8 \mathrm{eV}$ representing $\mathrm{PO}_{4}{ }^{3-}$ ion $[33,34]$ incorporated from solution; $\mathrm{O}$ 1s spectrum (Figure 2(e)) is formed by peaks for $\mathrm{O}^{2-}$ ion and adsorbed $\mathrm{H}_{2} \mathrm{O}$ and $\mathrm{OH}^{-}$ion; the peak of $\mathrm{OH}^{-}$ion at a binding energy of $531.8 \mathrm{eV}[33,34]$ shows the existence of oxygen from $\mathrm{PO}_{4}{ }^{3-}$ ion; the peak of $\mathrm{O}^{2-}$ ion at $529.5 \mathrm{eV}[35,36]$ confirms the formation of oxides; additionally, Ta $4 \mathrm{f}$ spectrum (Figure 2(b)) denotes the peaks for tantalum suboxides $[30,31]\left(\mathrm{Ta}_{2} \mathrm{O}, \mathrm{TaO}\right.$, and $\left.\mathrm{TaO}_{2}\right)$ at about $26 \mathrm{eV}$ and $28 \mathrm{eV}$; also, the doublet of $\mathrm{Zr} 3 \mathrm{~d}$ (Figure 2(c)) clearly ascertains the $\mathrm{ZrO}_{2}$ oxide $[30,31]$ at about $182 \mathrm{eV}$. It results that, by the anodic galvanostatic polarization at $12 \mathrm{~mA} / \mathrm{cm}^{2}$, for $50 \mathrm{~min}$
TABLE 1: Roughness of Ti-15Ta-5Zr alloy surface after anodic galvanostatic polarization.

\begin{tabular}{lcc}
\hline Electrodeposition conditions & RMS $(\mathrm{nm})$ & Rav $(\mathrm{nm})$ \\
\hline $0.5 \mathrm{M} \mathrm{H}_{3} \mathrm{PO}_{4}, 10 \mathrm{~mA} / \mathrm{cm}^{2}, 45 \mathrm{~min}$ & 10.52 & 8.73 \\
$1.1 \mathrm{M} \mathrm{H}_{3} \mathrm{PO}_{4}, 12 \mathrm{~mA} / \mathrm{cm}^{2}, 50 \mathrm{~min}$ & 55.83 & 40.67 \\
\hline
\end{tabular}

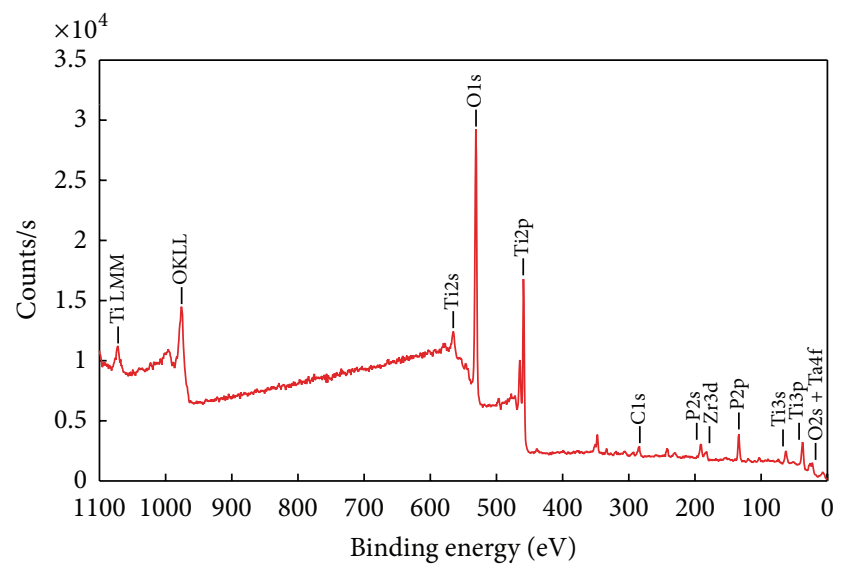

FIGURE 1: XPS survey spectrum for the nanolayer electrodeposited at $12 \mathrm{~mA} / \mathrm{cm}^{2}$, in $1.1 \mathrm{M} \mathrm{H}_{3} \mathrm{PO}_{4}$ solution for $50 \mathrm{~min}$.

in $1.1 \mathrm{M} \mathrm{H}_{3} \mathrm{PO}_{4}$ solution, the surface of Ti-15Ta-5Zr alloy was covered with a nanolayer formed by $\mathrm{TiO}_{2}, \mathrm{ZrO}_{2}$, oxides, tantalum suboxides, and $\mathrm{PO}_{4}{ }^{3-}$ ions incorporated in the time of the electrodeposition process. The presence of $\mathrm{PO}_{4}{ }^{3-}$ ions is very beneficial because these ions being the main inorganic component of the human bone will promote the ulterior codeposition of phosphate ions and will react with ions from the physiological fluid, which means bioactivity [2] and biocompatibility.

The thickness of the layer existing on the Ti-15Ta$5 \mathrm{Zr}$ alloy surface after anodic galvanostatic polarization at $12 \mathrm{~mA} / \mathrm{cm}^{2}$ for $50 \mathrm{~min}$ in $1.1 \mathrm{M} \mathrm{H}_{3} \mathrm{PO}_{4}$ solution was calculated from XPS depth profiling spectra as being $15.5 \mathrm{~nm} \pm 1.0 \mathrm{~nm}$ [37]; comparing with the thickness of $8.5 \mathrm{~nm} \pm 1 \mathrm{~nm}$ of the native passive film (unshown results), it appears that by the electrodeposition, the new layer doubled its thickness.

3.2. Topography and Roughness of the Electrodeposited Nanolayer. The topography and roughness play an important role for the interfacial reactions between the implant and local tissues [6]. AFM 3D images (Figure 3) revealed that in $0.5 \mathrm{M} \mathrm{H}_{3} \mathrm{PO}_{4}$ solution at a current density of $10 \mathrm{~mA} / \mathrm{cm}^{2}$ for $45 \mathrm{~min}$ was electrodeposited a nanolayer with nonporous topography (Figure 3(a)), while in $1.1 \mathrm{M} \mathrm{H}_{3} \mathrm{PO}_{4}$ solution at a current density of $12 \mathrm{~mA} / \mathrm{cm}^{2}$ for $50 \mathrm{~min}$, it resulted in a rough nanolayer with homogeneous roughness and porosity (Figure 3(b)). Table 1 evinced the differences between the roughness of these two electrodeposited nanolayers; namely, both RMS and Rav have five times higher values for the nanolayer obtained in $1.1 \mathrm{M} \mathrm{H}_{3} \mathrm{PO}_{4}$ solution at a current density of $12 \mathrm{~mA} / \mathrm{cm}^{2}$ for $50 \mathrm{~min}$. 


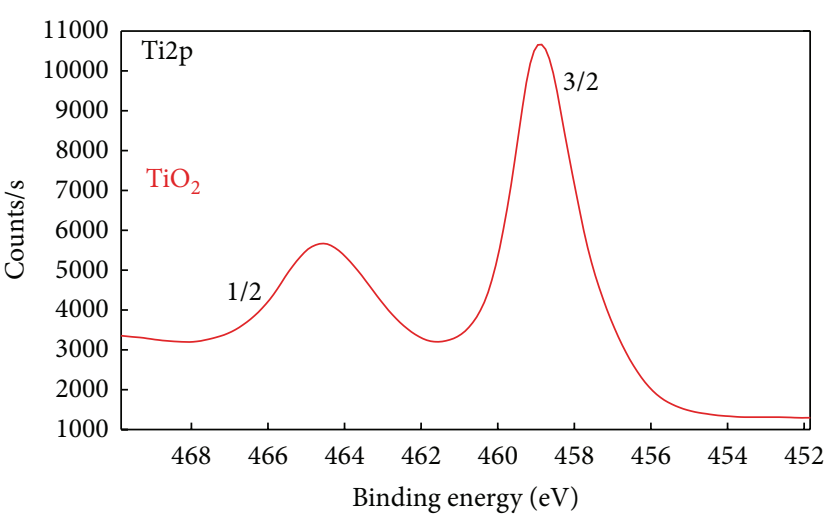

(a)

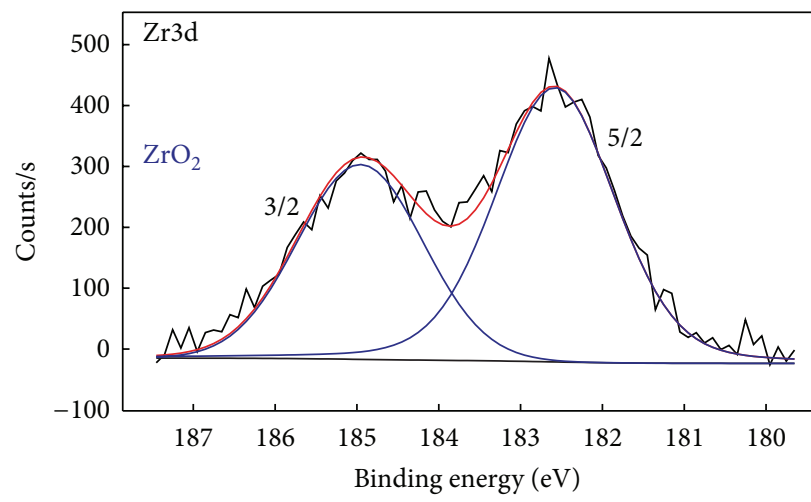

(c)

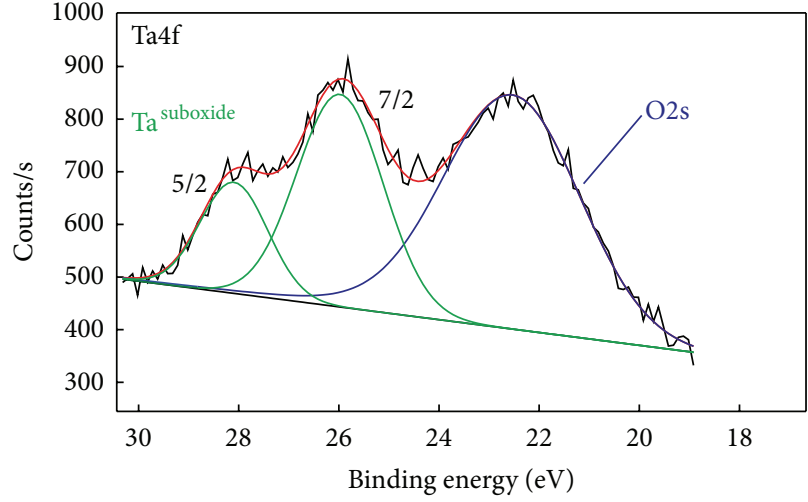

(b)

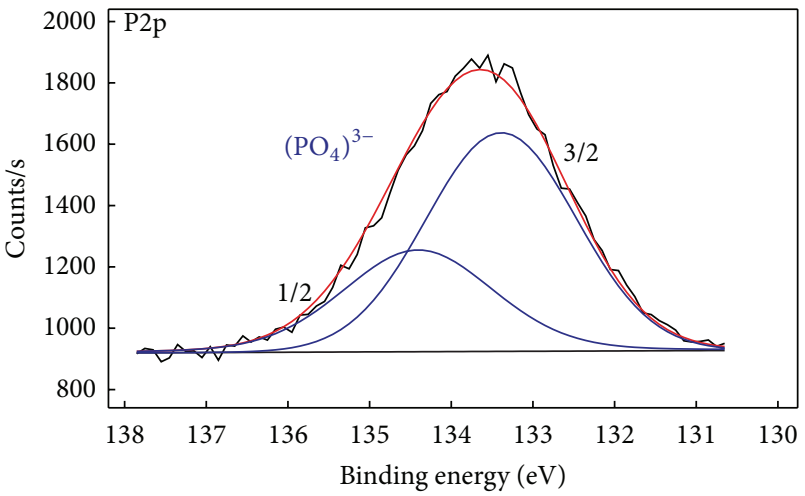

(d)

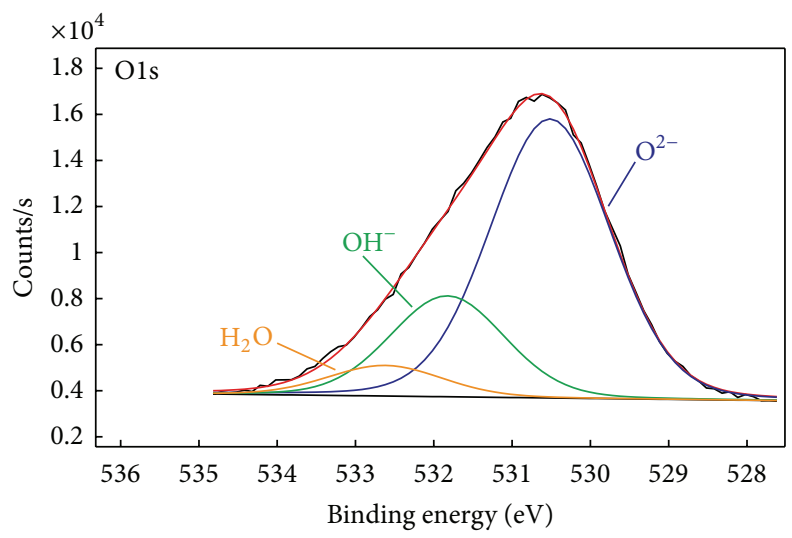

(e)

FIGURE 2: XPS high resolution spectra for the nanolayer electrodeposited at $12 \mathrm{~mA} / \mathrm{cm}^{2}$, in $1.1 \mathrm{M} \mathrm{H}_{3} \mathrm{PO}_{4}$ solution for $50 \mathrm{~min}$ : (a) Ti $2 \mathrm{p}$; (b) Ta 4f; (c) Zr 3d; (d) P 2p; (e) O 1s.

This roughness and the presence of $\mathrm{PO}_{4}{ }^{3-}$ anions on the Ti-15Ta-5Zr alloy surface favor the migration of the different ions into the pores of the nanolayer and reactions of ion exchange with the ions from the human body fluid; namely, the surface has polyanionic properties [6]; these facts promote the electrostatic bonds between electrodeposited nanolayer and proteins, fibronectin, fibroin, osteocalcin, and osteoblast, that is, biomineralization of this rough surface that so induces the growth of the bone tissue into pores and consequently a strong mechanical interlocking between implant surface and bone tissues [6]. Therefore, the nanolayer electrodeposited in $1.1 \mathrm{M} \mathrm{H}_{3} \mathrm{PO}_{4}$ solution at a current density of $12 \mathrm{~mA} / \mathrm{cm}^{2}$ for $50 \mathrm{~min}$, containing protective $\mathrm{TiO}_{2}, \mathrm{ZrO}_{2}$ oxides, tantalum suboxides, and $\mathrm{PO}_{4}^{3-}$ anions, has osteoinductive properties and develops a strong bone adhesion.

\subsection{Morphology and Porosity of the Electrodeposited} Nanolayer. SEM micrographs of high resolution (Figure 4) for the nanolayer electrodeposited in $1.1 \mathrm{M} \mathrm{H}_{3} \mathrm{PO}_{4}$ solution at a current density of $12 \mathrm{~mA} / \mathrm{cm}^{2}$ for 50 min presented a porous microstructure with fine porosity and pore diameter 


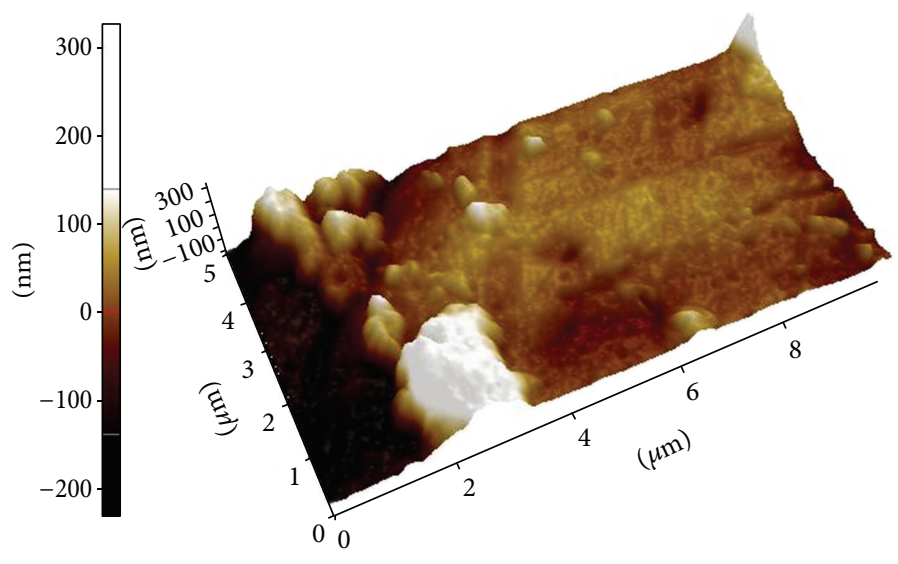

(a)

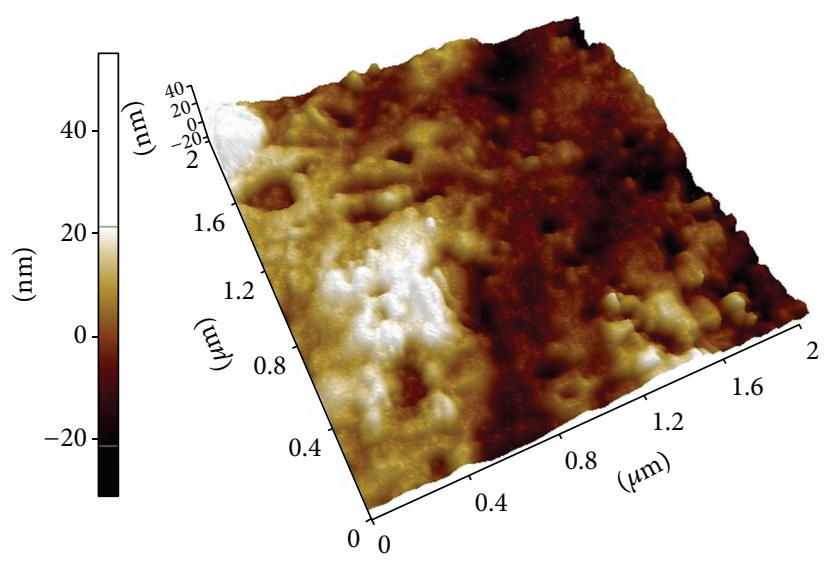

(b)

FIGURE 3: AFM 3D images for the electrodeposited nanolayers in (a) $0.5 \mathrm{M} \mathrm{H}_{3} \mathrm{PO}_{4}, 10 \mathrm{~mA} / \mathrm{cm}^{2}, 45 \mathrm{~min}$; (b) $1.1 \mathrm{M} \mathrm{H}_{3} \mathrm{PO}_{4}, 12 \mathrm{~mA} / \mathrm{cm}^{2}, 50 \mathrm{~min}$.

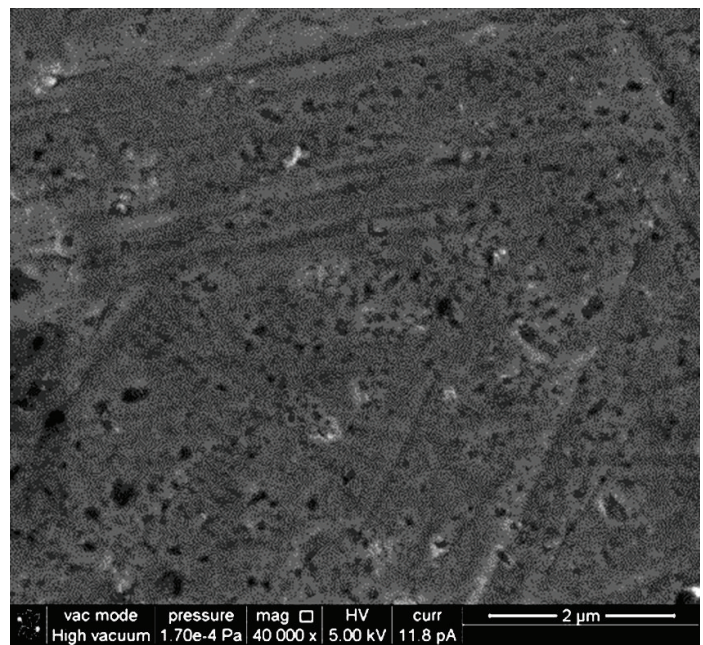

FIGURE 4: SEM micrograph for the nanolayer electrodeposited at $12 \mathrm{~mA} / \mathrm{cm}^{2}$, in $1.1 \mathrm{M} \mathrm{H}_{3} \mathrm{PO}_{4}$ solution for $50 \mathrm{~min}$.

of 20-50 nm. It was shown by Park et al. [38] that a diameter less than $30 \mathrm{~nm}$ provided an accelerated cell adhesion and spreading. Also, the nanoporous oxide layer can stimulate the growth of the bone tissue through them, leading to an anchorage, effective fusion with the bone $[8,12,13]$. Therefore, the pore dimensions of our obtained nanolayer are very suitable for an implant material.

XPS, AFM, and SEM analysis demonstrated that the electrodeposited film on the new Ti-15Ta-5Zr alloy surface by the anodic galvanostatic polarization at a current density of $12 \mathrm{~mA} / \mathrm{cm}^{2}$ for $50 \mathrm{~min}$ in $1.1 \mathrm{M} \mathrm{H}_{3} \mathrm{PO}_{4}$ solution was a phosphorous-enriched oxide nanolayer with very good roughness and porosity, that is able to increase the alloy bioactivity, to stimulate the cell growth, and to favor the osseointegration.

3.4. Electrochemical and Corrosion Stability of the Electrodeposited Nanolayer. The flat potentiodynamic polarization $\mathrm{cu}$ rves (Figure 5) of the bare and anodic oxidized $\mathrm{Ti}-15 \mathrm{Ta}-5 \mathrm{Zr}$ alloy in Ringer solutions of different $\mathrm{pH}$ values showed a passive behavior.

The corrosion, $E_{\text {corr }}$, and passivation, $E_{p}$, potentials (Table 2) for the anodic oxidized alloy shifted towards positive region in comparison with those of the bare alloy, evincing a nobler surface; this fact can be explained by the thicker oxide layer and by its composition enriched with phosphorous ions which inhibits the dissolution processes at the interface and leads to the ennoblement of $E_{\text {corr }}$ and $E_{p}$ [14-16]. Also, the passive current density, $i_{p}$, had lower values for the anodic oxidized alloy in comparison with the bare substrate proving that the electrodeposited nanolayer acts as an effective barrier against the aggressive ion entrance through it $[7,8]$. The large current plateau is indicative of the unique ion transfer reaction that conducts to the thickening of the oxide nanolayer according to the high field mechanism $[7,11,39]$. Tendency to passivation $\mid E_{\text {corr }}-$ $E_{p} \mid$ had lower values for the oxidized alloy as result of the strong passivation action exercised by the electrodeposited nanolayer. The noblest electrochemical behavior, the most favorable electrochemical parameters were registered for the 

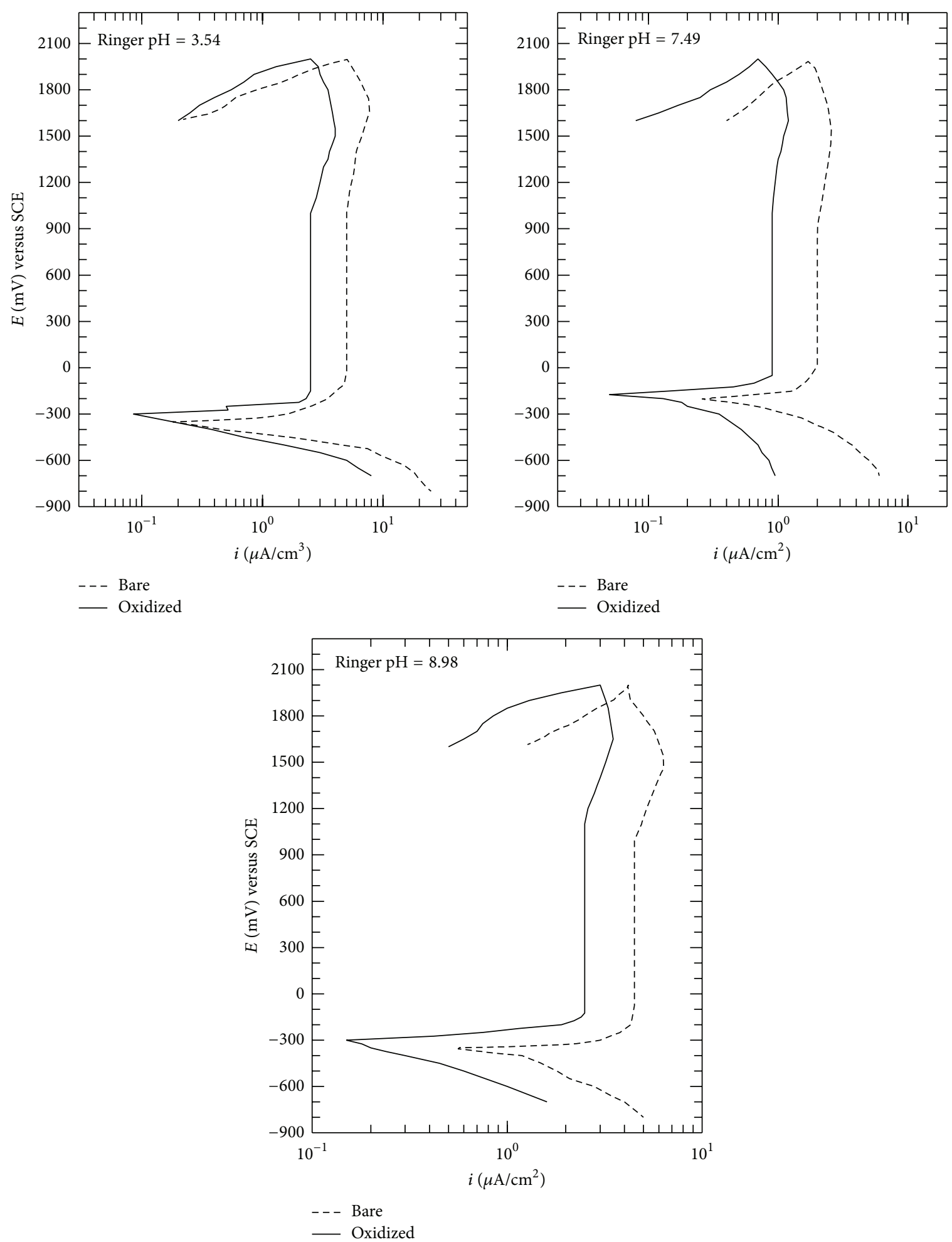

FIGURE 5: Cyclic potentiodynamic polarization curves for bare and anodic oxidized Ti-15Ta-5Zr alloy in Ringer solutions at $37^{\circ} \mathrm{C}$.

oxidized alloy in neutral Ringer solution, the condition in which an implant "works" the longest time period. In acid and alkaline Ringer solutions, slightly unfavorable electrochemical parameters were obtained, but their values demonstrate a passive, resistant state.
The potentiodynamic linear polarization curves, Tafel representation (an example is presented in Figure 6) furnished the main corrosion parameters. The alloy corrosion is very important factor because by corrosion can be released ions and corrosion products which may affect surrounding 
TABLE 2: Main electrochemical parameters for bare and anodic oxidized Ti-15Ta-5Zr alloy in Ringer solutions at $37^{\circ} \mathrm{C}$.

\begin{tabular}{|c|c|c|c|c|c|c|}
\hline \multirow{2}{*}{ Parameter } & \multicolumn{2}{|c|}{ Ringer $\mathrm{pH}=3.54$} & \multicolumn{2}{|c|}{ Ringer $\mathrm{pH}=7.49$} & \multicolumn{2}{|c|}{ Ringer $\mathrm{pH}=8.98$} \\
\hline & Bare & Oxidized & Bare & Oxidized & Bare & Oxidized \\
\hline$E_{\text {corr }}(\mathrm{mV})$ & -350 & -300 & -200 & -150 & -350 & -300 \\
\hline$E_{p}(\mathrm{mV})$ & -150 & -150 & -100 & -75 & -200 & -175 \\
\hline$\Delta E_{p}(\mathrm{mV})$ & $>2000$ & $>2000$ & $>2000$ & $>2000$ & $>2000$ & $>2000$ \\
\hline$\left|E_{\text {corr }}-E_{p}\right|(\mathrm{mV})$ & 200 & 150 & 100 & 75 & 150 & 125 \\
\hline$i_{p}\left(\mu \mathrm{A} / \mathrm{cm}^{2}\right)$ & 5.0 & 2.5 & 2.0 & 0.9 & 4.5 & 2.5 \\
\hline
\end{tabular}

TABLE 3: Main corrosion parameters for bare and anodic oxidized Ti-15Ta-5Zr alloy in Ringer solutions at $37^{\circ} \mathrm{C}$.

\begin{tabular}{lcccccc}
\hline \multirow{2}{*}{ Parameter } & \multicolumn{2}{c}{ Ringer $\mathrm{pH}=3.54$} & \multicolumn{2}{c}{ Ringer $\mathrm{pH}=7.49$} & \multicolumn{2}{c}{ Ringer $\mathrm{pH}=8.98$} \\
& Bare & Oxidized & Bare & Oxidized & Bare & Oxidized \\
\hline$i_{\text {corr }}\left(\mu \mathrm{A} / \mathrm{cm}^{2}\right)$ & 0.091 & 0.019 & 0.010 & 0.0053 & 0.061 & 0.032 \\
$V_{\text {corr }}(\mu \mathrm{m} /$ Year $)$ & 0.83 & 0.171 & 0.092 & 0.049 & 0.556 & 0.294 \\
$R_{p}\left(\mathrm{k} \Omega \cdot \mathrm{cm}^{2}\right)$ & 184 & 979 & 180 & 1879 & 133 & 945 \\
Ion release $\left(\mathrm{ng} / \mathrm{cm}^{2}\right)$ & 84.33 & 17.37 & 9.35 & 4.98 & 56.49 & 29.91 \\
Resistance class & PS & PS & PS & PS & PS \\
\hline
\end{tabular}

PS: perfect stable.

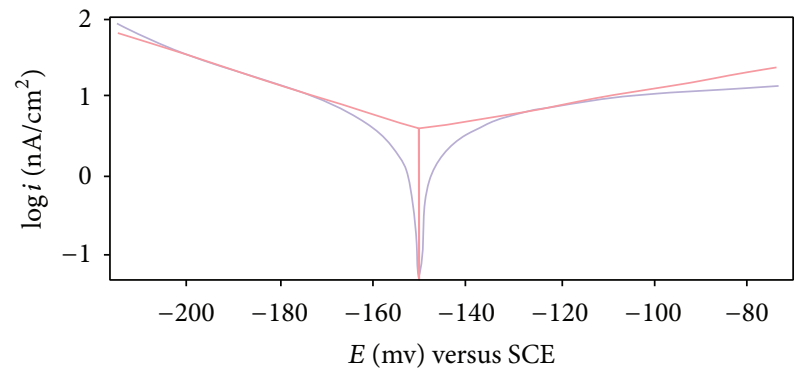

FIGURE 6: Tafel representation for anodic oxidized Ti-15Ta-5Zr alloy in Ringer solution of $\mathrm{pH}=7.49$ at $37^{\circ} \mathrm{C}$.

tissues and may cause inflammatory processes. Applying the anodic galvanostatic oxidation, a thicker nanolayer was formed on the alloy surface that improved all corrosion parameters.

From Table 3 it results in the pronounced decrease (about 7 times) for the values of $i_{\text {corr }}$, and $V_{\text {corr }}$; also, the total quantity of ions released into physiological Ringer solutions decreased very much; namely, the toxicity of the anodic oxidized alloy is much lower than that of the bare one. Comparing with the results of other authors, it appears that our electrodeposited nanolayer confers superior protection to its substrate: Narayanan and Seshadri [16] determined $i_{\text {corr }}$ of $0.011 \mu \mathrm{A} / \mathrm{cm}^{2}$ in neutral Ringer solution for Ti-6Al-4V alloy covered with a layer of $280 \mathrm{~nm}$ thickness; our $i_{\text {corr }}$ is $0.0053 \mu \mathrm{A} / \mathrm{cm}^{2}$; Simka [8] obtained $i_{\text {corr }}=0.010 \mu \mathrm{A} / \mathrm{cm}^{2}$ for Ti-13Nb-13Zr alloy anodized at $80 \mathrm{~V}$, thickness of $5-10 \mathrm{~nm}$; Jakubowicz et al. [9] realized $i_{\text {corr }}=12.5 \mu \mathrm{A} / \mathrm{cm}^{2}$ for Ti- $6 \mathrm{Zr}$ $4 \mathrm{Nb}$ alloy anodic oxidized at $10 \mathrm{~V}$. Polarization resistance, $R_{p}$, increased of about 5-10 times in comparison with the bare alloy; that is, the electrodeposited nanolayer put up a much higher resistance to the ion migration through it from metal to solution and inversely [8]. A $R_{p}$ value of $1.879 \mathrm{M} \Omega \cdot \mathrm{cm}^{2}$ in neutral Ringer solution is higher than that of $1.160 \mathrm{M} \Omega \cdot \mathrm{cm}^{2}$ measured by Simka [8] for Ti-13Nb-13Zr alloy. The best values for the corrosion parameters were found in neutral Ringer solution, characterizing a "Perfect Stable" resistance class both for bare and oxidized Ti-15Ta-5Zr alloy. Though in acid and alkaline Ringer solutions, less unfavorable parameters were registered, and the two alloys are very resistant, being placed in the same "Perfect Stable" class. Therefore, the electrodeposited nanolayer can protect the alloy from the ion release, minimizing the adverse reactions and increasing its biocompatibility.

Nyquist spectra [15] (Figure 7) recorded in Ringer solutions evinced larger semicircles with bigger radii and higher impedance values for the oxidized alloy in comparison with the bare one; these facts show a capacitive behavior, a film with dielectric properties and that the electrodeposited nanolayer has more insulating, more protective properties and is thicker than that on the bare alloy surface, as was proved by XPS analysis. Also, the best capacitive behavior, the most resistant nanolayer resulted in neutral Ringer solution. Some inflexions can be observed on Nyquist spectra, which denote inhomogeneous films consisting from two or more layers $[8,40]$.

Bode phase angle plots $[11,13,14,19]$ (Figure 8 ) revealed in the low and middle frequency range two phase angles with very high values (between $-79^{\circ}$ and $-86^{\circ}$ ) describing the same capacitive behavior. The anodic oxidized alloy had higher phase angles, with $2^{\circ}-3^{\circ}$ higher than those of the bare one; these phase angles had values of $-85^{\circ} \div-86^{\circ}$ which indicate a protective film with more insulating properties conferred by the thicker electrodeposited nanolayer [11, 19]; the higher phase angles show a more capacitive, compact, denser, barrier layer (in contact with the metallic substrate), and very resistant to the crossing of the ions through it. The lower phase angles of about $-79^{\circ} \div-82^{\circ}$ suggest a more 

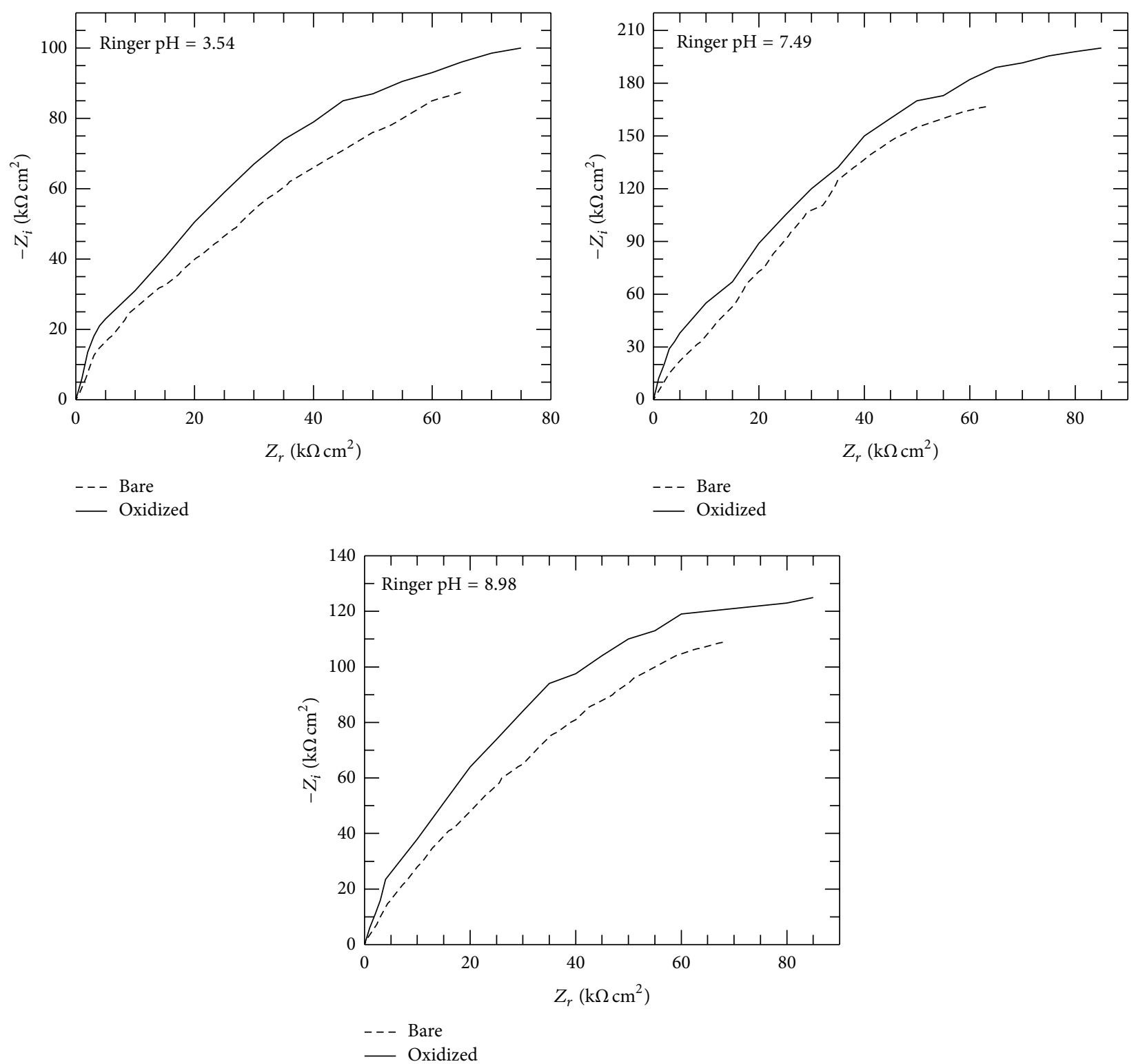

Figure 7: Nyquist spectra for bare and anodic oxidized Ti-15Ta-5Zr alloy in Ringer solutions at $37^{\circ} \mathrm{C}$.

permissive, porous layer (in contact with the electrolyte) that permits the absorption of the different ions, compounds, and species from solution into its pores $[13,14,41]$; these pores can stimulate the adsorption and growth of the osteoblast cells through them, producing their strong binding [13]. The thicker, denser, more compact electrodeposited nanolayer that contains both protective $\mathrm{Ti}$, $\mathrm{Ta}$, and $\mathrm{Zr}$ oxides and $\mathrm{PO}_{4}{ }^{3-}$ ions (XPS data) can reduce the potential gradient across the $\mathrm{metal} /$ nanolayer/solution interface, thus reducing the anodic dissolution.

EIS spectra were modeled with two time constant equivalent electric circuit (Figure 9). Many authors $[11,13,14]$ used this equivalent circuit to describe the bilayered structure of the surface films grown by the electrochemical anodization. The fitted electric equivalent circuit reflects the barrier properties of the inner, dense, compact layer by its resistance, $R_{1}$, and capacitance, $\mathrm{CPE}_{1}$, and those of porosity of the outer, less protective porous layer by its resistance, $R_{2}$, and capacitance, $\mathrm{CPE}_{2}$ (instead of capacitance, $Q$ was used constant phase element, CPE that represents a nonideal capacitance).

The impedance parameters from Table 4 showed that the inner, barrier layer resistance, $R_{1}$, is higher of two orders of magnitude than that of the porous layer, $R_{2}$, demonstrating a very resistive, protective, inner layer [19]; the lower inner layer capacitance, $\mathrm{CPE}_{1}$, than that of the porous one, $\mathrm{CPE}_{2}$, can be related to the thickening of this barrier layer [14]. The higher values of $\mathrm{nl}$ parameter between 0.96 and 0.99 in comparison with those of $\mathrm{n} 2$ parameter of 0.91-0.93 indicate that the inner barrier layer closed to an ideal capacitor, being the layer that confers real protection to the substrate $[11,19]$. All impedance parameters had more favorable values for the anodic oxidized Ti-15Ta-5Zr alloy comparing with the bare 

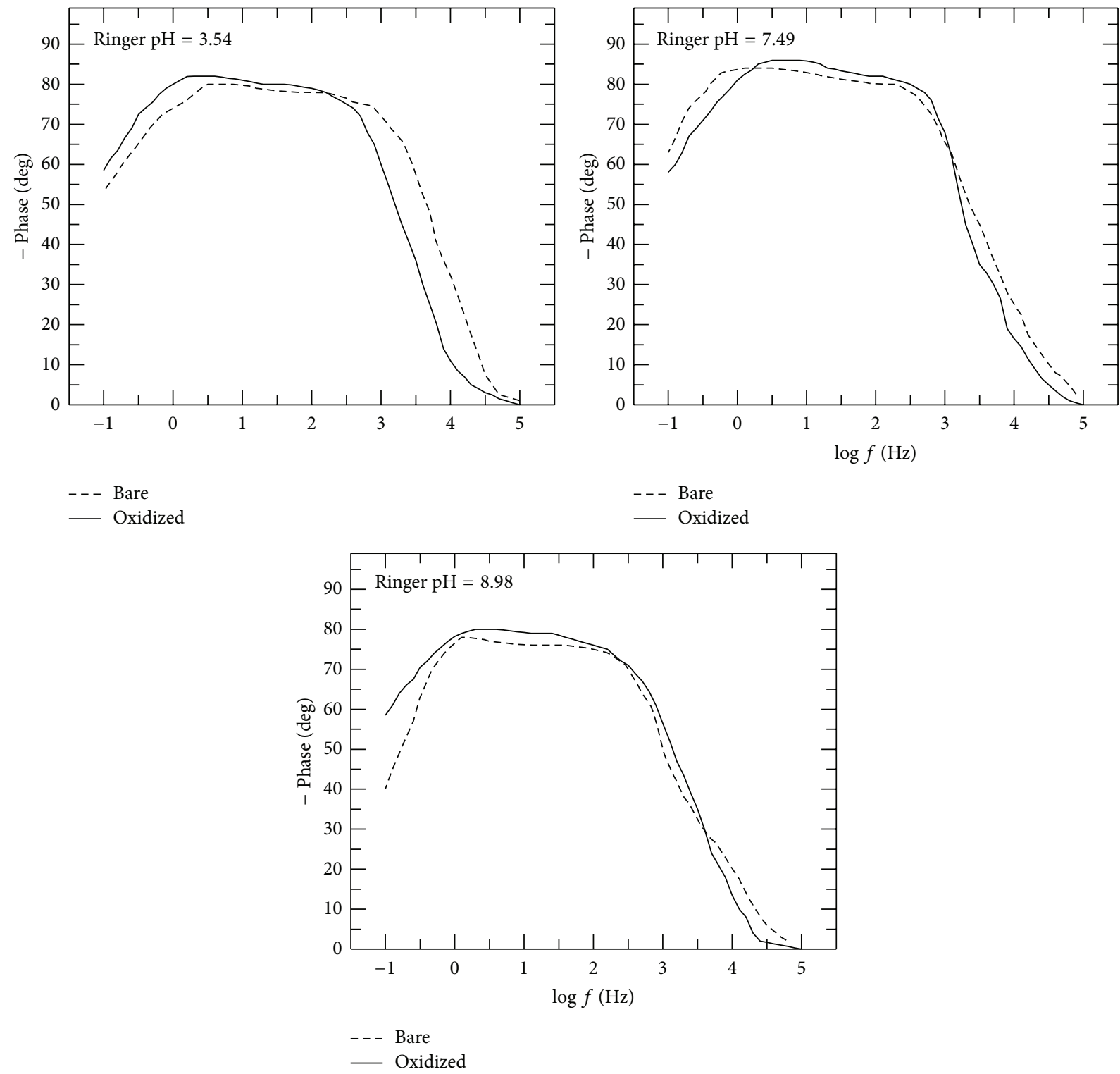

FIGURE 8: Bode spectra for bare and anodic oxidized Ti-15Ta-5Zr alloy in Ringer solutions at $37^{\circ} \mathrm{C}$.

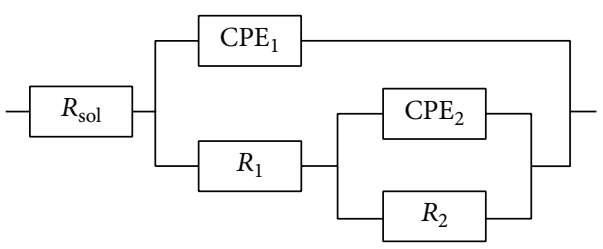

Figure 9: Electric equivalent circuit with two time constants.

one, due to the thicker, denser, more compact electrodeposited nanolayer that contains, in addition, protective and bioactive phosphate ions.

3.5. Long-Term Behavior of the Electrodeposited Nanolayer. The long-term behavior (500 immersion hours) of the bare and anodic oxidized Ti-15Ta-5Zr alloy was studied by the monitoring of the open circuit potentials, $E_{o c}$, and corresponding open circuit potential gradients, $\Delta E_{\mathrm{oc}}$.

$E_{\text {oc }}$ (Figure 10) increased over time with almost $100 \mathrm{mV}$ to more positive values; such behavior indicates the thickening $[42,43]$ of the native passive film for the bare alloy and of the electrodeposited nanolayer for the oxidized alloy, namely, a certain activity into the physiological solutions $[8,13]$. The fact that the $E_{\mathrm{oc}}$ values for the oxidized alloy are nobler than those for the bare alloy can be explained taking into consideration the higher thickness and the more favorable composition containing incorporated, protective phosphate ions of the electrodeposited nanolayer which lead to the ennoblement of its open circuit potentials $[8,12]$. The open circuit potentials reached almost constant values after about 250 immersion hours, proving a resistant, stable state. The most 
TABLE 4: Impedance parameters for bare and anodic oxidized Ti-15Ta-5Zr alloy in Ringer solutions at $37^{\circ} \mathrm{C}$.

\begin{tabular}{lcccccc}
\hline \multirow{2}{*}{ Parameter } & \multicolumn{2}{c}{ Ringer $\mathrm{pH}=3.54$} & \multicolumn{2}{c}{ Ringer $\mathrm{pH}=7.49$} & \multicolumn{2}{c}{ Ringer $\mathrm{pH}=8.98$} \\
& Bare & Oxidized & Bare & Oxidized & Bare & Oxidized \\
\hline$R_{\mathrm{sol}}\left(\Omega \cdot \mathrm{cm}^{2}\right)$ & 13.2 & 13.9 & 14.1 & 14.7 & 13.4 & 13.9 \\
$R_{1}\left(\Omega \cdot \mathrm{cm}^{2}\right)$ & $7.9 \times 10^{6}$ & $8.5 \times 10^{6}$ & $8.7 \times 10^{6}$ & $9.9 \times 10^{6}$ & $7.5 \times 10^{6}$ & $8.3 \times 10^{6}$ \\
$\mathrm{CPE}_{1}\left(\mathrm{~S} \cdot \mathrm{s}^{n} / \mathrm{cm}^{2}\right)$ & $2.7 \times 10^{-6}$ & $1.7 \times 10^{-6}$ & $3.1 \times 10^{-6}$ & $1.5 \times 10^{-6}$ & $2.4 \times 10^{-5}$ & $1.9 \times 10^{-5}$ \\
$n 1$ & 0.97 & 0.98 & 0.98 & 0.99 & 0.96 & 0.97 \\
$R_{2}\left(\Omega \cdot \mathrm{cm}^{2}\right)$ & $1.6 \times 10^{4}$ & $1.8 \times 10^{4}$ & $2.1 \times 10^{4}$ & $2.5 \times 10^{4}$ & $1.8 \times 10^{4}$ & $2.1 \times 10^{4}$ \\
$\mathrm{CPE}_{2}\left(\mathrm{~S} \cdot \mathrm{s}^{n} / \mathrm{cm}^{2}\right)$ & $1.5 \times 10^{-5}$ & $1.2 \times 10^{-5}$ & $1.1 \times 10^{-5}$ & $1.0 \times 10^{-5}$ & $1.4 \times 10^{-5}$ & $1.2 \times 10^{-5}$ \\
$n 2$ & 0.91 & 0.92 & 0.92 & 0.93 & 0.91 & 0.92 \\
\hline
\end{tabular}
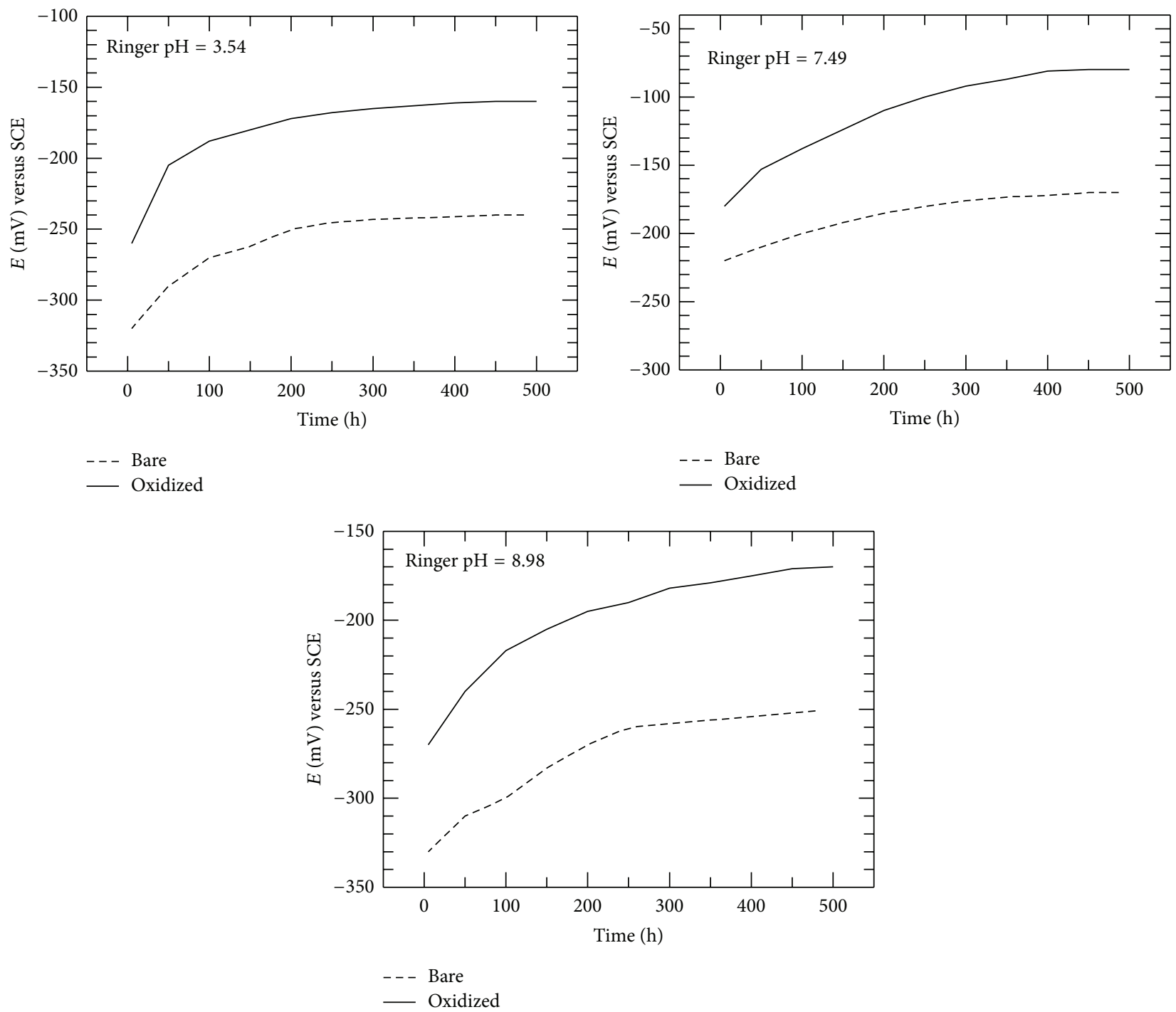

FIgURE 10: $E_{\text {oc }}$ versus time for bare and anodic oxidized Ti-15Ta-5Zr alloy in Ringer solutions at $37^{\circ} \mathrm{C}$.

electropositive values of $E_{\mathrm{oc}}$ were registered in neutral Ringer solution, that is, the most protective, resistant behavior.

The open circuit potential gradients, $\Delta E_{\mathrm{oc}}(\mathrm{pH})$, which can appear along the implant surface, due to the local $\mathrm{pH}$ nonuniformity of the physiological fluid are presented in
Table 5; very low values were obtained; these gradient values cannot initiate galvanic cells or local corrosion, because, as was shown by many authors $[35,36,44]$, only potential differences of $0.6-0.7 \mathrm{~V}$ can develop these kinds of corrosion. Therefore, both bare and anodic oxidized Ti-15Ta-5Zr alloy 
TABLE 5: Open circuit potential gradients versus time for bare and anodic oxidized Ti-15Ta-5Zr alloy in Ringer solutions at $37^{\circ} \mathrm{C}$.

\begin{tabular}{lcccc}
\hline Ti-15Ta-5Zr & Time & $\Delta E_{\mathrm{oc1}}(\mathrm{mV})$ & $\Delta E_{\mathrm{oc} 2}(\mathrm{mV})$ & $\Delta E_{\mathrm{oc} 3}(\mathrm{mV})$ \\
\hline \multirow{3}{*}{ Bare } & 0 & -70 & -67 & 3 \\
& 200 & -35 & -18 & 17 \\
& 500 & -31 & -28 & 30 \\
\hline \multirow{3}{*}{ Oxidized } & 0 & -80 & 10 & 110 \\
& 200 & -62 & 23 & 85 \\
& 500 & -80 & 10 & 90 \\
\hline
\end{tabular}

have no susceptibility to galvanic or local corrosion for long term (500 exposure hours till present) even in severe functional conditions of extreme $\mathrm{pH}$ values.

It showed that the electrodeposited nanolayer can assure long-term corrosion resistance.

\section{Conclusions}

XPS, AFM, and SEM analysis demonstrated that the electrodeposited film on the new Ti-15Ta-5Zr alloy surface, by the anodic galvanostatic polarization at a current density of $12 \mathrm{~mA} / \mathrm{cm}^{2}$ for $50 \mathrm{~min}$ in $1.1 \mathrm{M} \mathrm{H}_{3} \mathrm{PO}_{4}$ solution was a phosphorous-enriched oxide nanolayer with very good roughness and porosity, proper microstructure, composition and thickness. All electrochemical parameters for the oxidized alloy had more favorable values than those of the bare alloy, indicative of the strong passivation action exercised by the electrodeposited nanolayer. The anodic oxidation nanolayer improved all corrosion parameters conferring superior protection to the Ti-15Ta-5Zr alloy substrate by its higher resistance to the ion migration through it. Impedance spectra revealed that the electrodeposited nanolayer has more insulating, protective properties and is thicker (as was proved by XPS determinations) in comparison with the native film on the bare alloy surface. The electrodeposited nanolayer is formed by an inner, compact, dense, barrier layer, very resistant to the crossing of the ions through it, and an outer, more permissive, porous layer that permits the absorption of the different species, stimulating the growth and strong binding of the bone cells. The open circuit potentials increased over time with almost $100 \mathrm{mV}$ to more positive values; such behavior indicates the thickening of the electrodeposited nanolayer, namely, its bioactivity. The oxidized nanolayer is able to protect the alloy from ion release, to assure longterm corrosion resistance, to minimize adverse reactions, to increase the alloy bioactivity, to stimulate the cell growth, and to favor the osseointegration.

\section{Conflict of Interests}

The authors declare that there is no conflict of interests regarding the publication of this paper.

\section{Acknowledgments}

This work was supported by Romanian UEFSCDI, Project no. TE 18/2013. Support of the EU (ERDF) and Romanian Government infrastructure POS-CCE O 2.2.1 Project INFRANANOCHEM no. 19/2009 is gratefully acknowledged.

\section{References}

[1] Z. Li, C. Ning, D. Ding, H. Liu, and L. Huang, "Biological properties of Ti-Nb-Zr-O nanostructures grown on Ti35Nb5Zr alloy," Journal of Nanomaterials, vol. 2012, Article ID 834042, 7 pages, 2012.

[2] P. K. Zysset, X. E. Guo, C. E. Hoffler, K. E. Moore, and S. A. Goldstein, "Mechanical properties of human trabecular bone lamellae quantified by nanoindentation," Technology and Health Care, vol. 6, no. 5-6, pp. 429-432, 1998.

[3] M. Niinomi, "Recent research and development in titanium alloys for biomedical applications and healthcare goods," Science and Technology of Advanced Materials, vol. 4, no. 5, pp. 445-454, 2003.

[4] V. S. Saji and H. C. Choe, "Electrochemical corrosion behaviour of nanotubular Ti-13Nb-13Zr alloy in Ringer's solution," Corrosion Science, vol. 51, no. 8, pp. 1658-1663, 2009.

[5] C.-K. Lee, "Fabrication, characterization and wear corrosion testing of bioactive hydroxyapatite/nano- $\mathrm{TiO}_{2}$ composite coatings on anodic Ti-6Al-4V substrate for biomedical applications," Materials Science and Engineering B, vol. 177, no. 11, pp. 810-818, 2012.

[6] E. Peláez-Abellán, L. Rocha-Sousa, W.-D. Müller, and A. C. Guastaldi, "Electrochemical stability of anodic titanium oxide films grown at potentials higher than $3 \mathrm{~V}$ in a simulated physiological solution," Corrosion Science, vol. 49, no. 3, pp. 1645-1655, 2007.

[7] M. P. Neupane, I. S. Park, S. J. Lee, K. A. Kim, M. H. Lee, and T. S. Bae, "Study of anodic oxide films of titanium fabricated by voltammetric technique in phosphate buffer media," International Journal of Electrochemical Science, vol. 4, no. 2, pp. 197207, 2009.

[8] W. Simka, "Preliminary investigations on the anodic oxidation of Ti-13Nb-13Zr alloy in a solution containing calcium and phosphorus," Electrochimica Acta, vol. 56, no. 27, pp. 9831-9837, 2011.

[9] J. Jakubowicz, G. Adamek, M. U. Jurczyk, and M. Jurczyk, “3D surface topography study of the biofunctionalised nanocrystalline Ti-6Zr-4Nb/Ca-P," Materials Characterization, vol. 70, pp. 55-62, 2012.

[10] M. V. Popa, E. Vasilescu, P. Drob et al., "Corrosion resistance improvement of titanium base alloys," Quimica Nova, vol. 33, no. 9, pp. 1892-1896, 2010.

[11] M. T. Woldemedhin, D. Raabe, and A. W. Hassel, "Characterization of thin anodic oxides of Ti-Nb alloys by electrochemical impedance spectroscopy," Electrochimica Acta, vol. 82, pp. 324332, 2012.

[12] S.-E. Kim, S.-B. Lee, S.-W. Kwak, C.-K. Kim, and K. N. Kim, "Nanoporous anodic oxidation titanium enhances cell proliferation and differentiation of immortalized mouse embryonic cells," Surface \& Coatings Technology, vol. 228, supplement 1, pp. S37-S42, 2013.

[13] L. T. Duarte, S. R. Biaggio, R. C. Rocha-Filho, and N. Bocchi, "Surface characterization of oxides grown on the Ti-13Nb-13Zr 
alloy and their corrosion protection," Corrosion Science, vol. 72, pp. 35-40, 2013.

[14] A. Gomez Sanchez, J. Ballarre, J. C. Orellano, G. Duffo, and S. Cere, "Surface modification of zirconium by anodisation as material for permanent implants: in vitro and in vivo study," Journal of Materials Science: Materials in Medicine, vol. 24, no. 1, pp. 161-169, 2013.

[15] R. Narayanan and S. K. Seshadri, "Phosphoric acid anodization of Ti-6Al-4V-structural and corrosion aspects," Corrosion Science, vol. 49, no. 2, pp. 542-558, 2007.

[16] R. Narayanan and S. K. Seshadri, "Point defect model and corrosion of anodic oxide coatings on Ti-6Al-4V", Corrosion Science, vol. 50, no. 6, pp. 1521-1529, 2008.

[17] Y. Shibata, D. Suzuki, S. Omori et al., "The characteristics of in vitro biological activity of titanium surfaces anodically oxidized in chloride solutions," Biomaterials, vol. 31, no. 33, pp. 8546$8555,2010$.

[18] H. Habazaki, M. Teraoka, Y. Aoki, P. Skeldon, and G. E. Thompson, "Formation of porous anodic titanium oxide films in hot phosphate/glycerol electrolyte," Electrochimica Acta, vol. 55, no. 12, pp. 3939-3943, 2010.

[19] S. K. Poznyak, A. D. Lisenkov, M. G. S. Ferreira, A. I. Kulak, and M. L. Zheludkevich, "Impedance behaviour of anodic $\mathrm{TiO}_{2}$ films prepared by galvanostatic anodisation and powerful pulse discharge in electrolyte," Electrochimica Acta, vol. 76, pp. 453461, 2012.

[20] M. V. Popa, I. Demetrescu, E. Vasilescu, P. Drob, D. Ioniţă, and C. Vasilescu, "Stability of some dental implant materials in oral biofluids," Revue Roumaine de Chimie, vol. 50, no. 5, pp. 399406, 2005.

[21] M. V. Popa, E. Vasilescu, P. Drob, and C. Vasilescu, “The modeling of passive film formation on a new industrial titanium alloy in very aggressive environment," Revista de Chimie, vol. 56, no. 9, pp. 908-912, 2005.

[22] E. Vasilescu, P. Drob, C. Vasilescu et al., "Corrosion resistance of the new Ti-25Ta-25Nb alloy in severe functional conditions," Materials and Corrosion, vol. 61, no. 11, pp. 947-954, 2010.

[23] M. V. Popa, J. M. C. Moreno, M. Popa et al., "Electrochemical deposition of bioactive coatings on Ti and Ti-6Al-4V surfaces," Surface and Coatings Technology, vol. 205, no. 20, pp. 47764783, 2011.

[24] D. Portan, D. Ionita, and I. Demetrescu, "Monitoring $\mathrm{TiO}_{2}$ nanotubes elaboration condition, a way for obtaining various characteristics of nanostructures," Key Engineering Materials, vol. 415, pp. 9-12, 2009.

[25] M. Mîndroiu, C. Pirvu, R. Ion, and I. Demetrescu, "Comparing performance of nanoarchitectures fabricated by Ti6Al7Nb anodizing in two kinds of electrolytes," Electrochimica Acta, vol. 56, no. 1, pp. 193-202, 2010.

[26] M. Prodana, D. Ionita, C. Ungureanu, D. Bojin, and I. Demetrescu, "Enhancing antibacterial effect of multiwalled carbon nanotubes using silver nanoparticles," Digest Journal of Nanomaterials and Biostructures, vol. 6, no. 2, pp. 549-556, 2011.

[27] E. Vasilescu, P. Drob, D. Raducanu et al., "Effect of thermomechanical processing on the corrosion resistance of Ti6Al4V alloys in biofluids," Corrosion Science, vol. 51, no. 12, pp. 28852896, 2009.

[28] M. A. Baker, S. L. Assis, R. Grilli, and I. Costa, "Investigation of the electrochemical behaviour and surface chemistry of a Ti$13 \mathrm{Nb}-13 \mathrm{Zr}$ alloy exposed in MEM cell culture media with and without the addition of $\mathrm{H}_{2} \mathrm{O}_{2}$," Surface and Interface Analysis, vol. 40, no. 3-4, pp. 220-224, 2008.
[29] R. Van Noort, “Titanium: the implant material of today," Journal of Materials Science, vol. 22, no. 11, pp. 3801-3811, 1987.

[30] J. F. Moulder, W. F. Stickle, P. E. Sobol, and K. D. Bomben, Handbook of X-Ray Photoelectron Spectroscopy, Physical Electronics, Chamhassen, Minn, USA, 1995.

[31] A. V. Naumkin, A. Kraut-Vass, S. W. Gaarenstroom, and C. J. Powell, "NIST X-ray photoelectron spectroscopy database," in NIST Standard Reference Database 20, Version 4.1, US Secretary of Commerce on behalf of the United States of America, Washington, DC, USA, 2012.

[32] T. Kasuga, M. Nogami, M. Niinomi, and T. Hattori, "Bioactive calcium phosphate invert glass-ceramic coating on $\beta$-type Ti29Nb-13Ta-4.6Zr alloy," Biomaterials, vol. 24, no. 2, pp. 283-290, 2003.

[33] S. J. Li, R. Yang, M. Niinomi, Y. L. Hao, and Y. Y. Cui, "Formation and growth of calcium phosphate on the surface of oxidized Ti$29 \mathrm{Nb}-13 \mathrm{Ta}-4.6 \mathrm{Zr}$ alloy," Biomaterials, vol. 25 , no. 13 , pp. $2525-$ 2532, 2004.

[34] I. S. Park, U. J. Choi, H. K. Yi, B. K. Park, M. H. Lee, and T. S. Baea, "Biomimetic apatite formation and biocompatibility on chemically treated Ti-6Al-7Nb alloy," Surface and Interface Analysis, vol. 40, no. 1, pp. 37-42, 2008.

[35] G. Sheela, M. Ramasamy, C. R. K. Rao, and M. Pushpavanam, "Electrochemical assessment on corrosion behaviour of electrochemically joined dissimilar metal joints," Bulletin of Electrochemistry, vol. 17, no. 8, pp. 347-350, 2001.

[36] E. Blasco-Tamarit, A. Igual-Muñoz, J. G. Antón, and D. M. García-García, "Galvanic corrosion of titanium coupled to welded titanium in $\mathrm{LiBr}$ solutions at different temperatures," Corrosion Science, vol. 51, no. 5, pp. 1095-1102, 2009.

[37] D. R. Baer, M. H. Engelhard, A. S. Lea et al., "Comparison of the sputter rates of oxide films relative to the sputter rate of $\mathrm{SiO} 2$," Journal of Vacuum Science and Technology A: Vacuum, Surfaces and Films, vol. 28, no. 5, pp. 1060-1072, 2010.

[38] J. Park, S. Bauer, K. Von Der Mark, and P. Schmuki, "Nanosize and vitality: $\mathrm{TiO}_{2}$ nanotube diameter directs cell fate," Nano Letters, vol. 7, no. 6, pp. 1686-1691, 2007.

[39] M. M. Lohrengel, “Thin anodic oxide layers on aluminium and other valve metals: high field regime," Materials Science and Engineering R: Reports, vol. 11, no. 6, pp. 243-294, 1993.

[40] S. L. Assis and I. Costa, "Electrochemical evaluation of Ti-13Nb13Zr, Ti-6Al-4V and Ti-6Al-7Nb alloys for biomedical application by long-term immersion tests," Materials and Corrosion, vol. 58, no. 5, pp. 329-333, 2007.

[41] S. Tamilselvi and N. Rajendran, "In vitro corrosion behaviour of Ti-5Al-2Nb-1Ta alloy in Hanks solution," Materials and Corrosion, vol. 58, no. 4, pp. 285-289, 2007.

[42] J. Black, Biological Performance of Materials: Fundamentals of Biocompatibility, Marcel Dekker, New York, NY, USA, 1992.

[43] D. J. Blackwood, A. W. C. Chua, K. H. W. Seah, R. Thampuran, and S. H. Teoh, "Corrosion behaviour of porous titaniumgraphite composites designed for surgical implants," Corrosion Science, vol. 42, no. 3, pp. 481-503, 2000.

[44] Q. K. Guo, M. Du, and C. J. Zhou, "Study of galvanic corrosion of carbon steel/titanium and carbon steel/titanium/navel brass in seawater," in Proceedings of the 16th International Corrosion Congress, paper 08-28, pp. 08-28, Beijing, China, September 2005. 

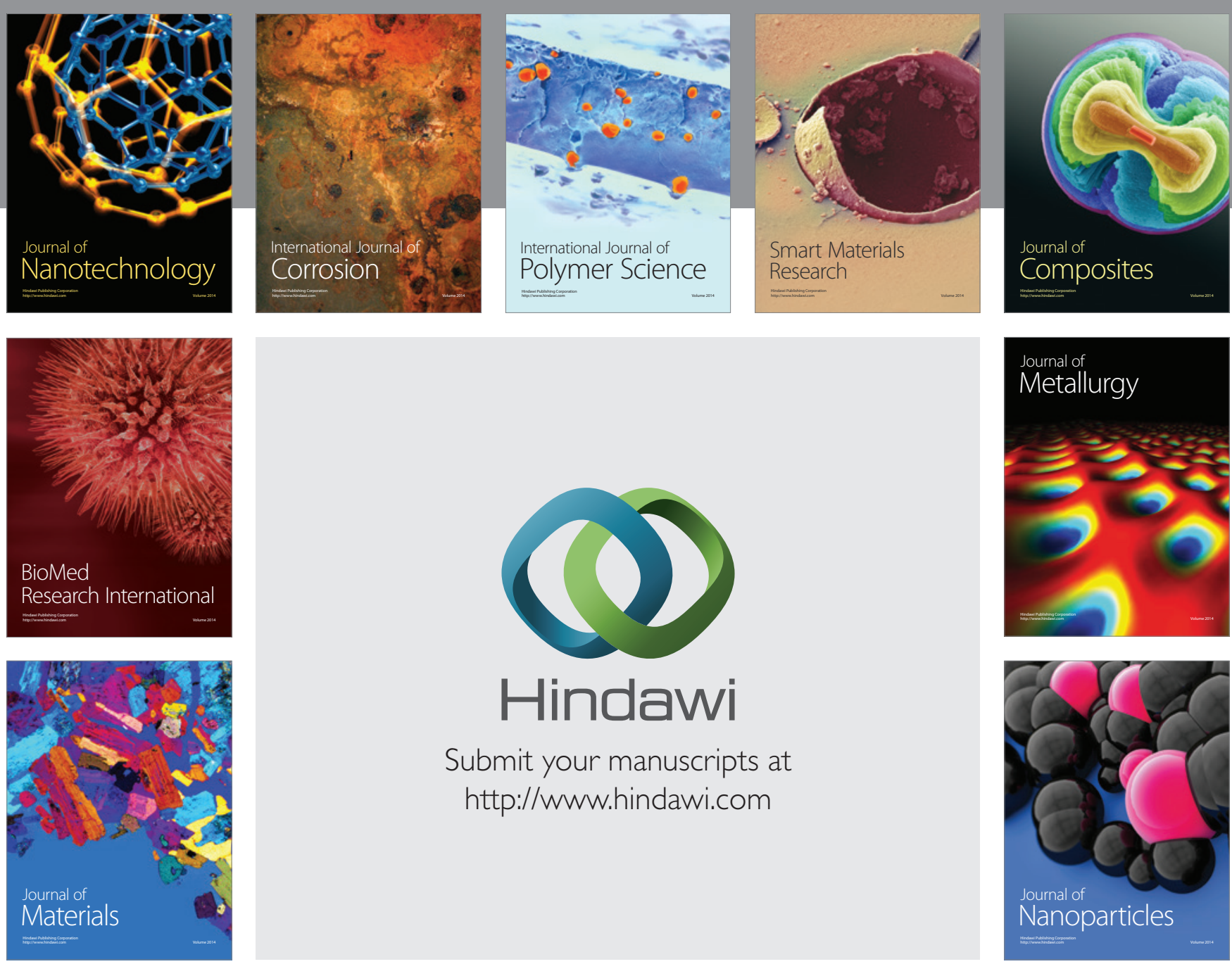

Submit your manuscripts at http://www.hindawi.com
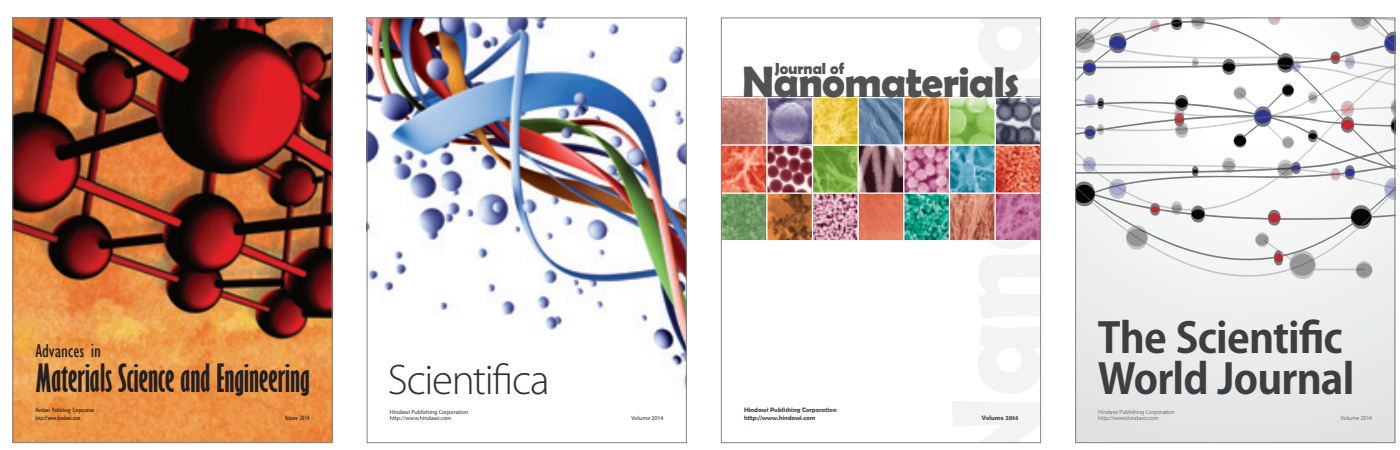

\section{The Scientific World Journal}
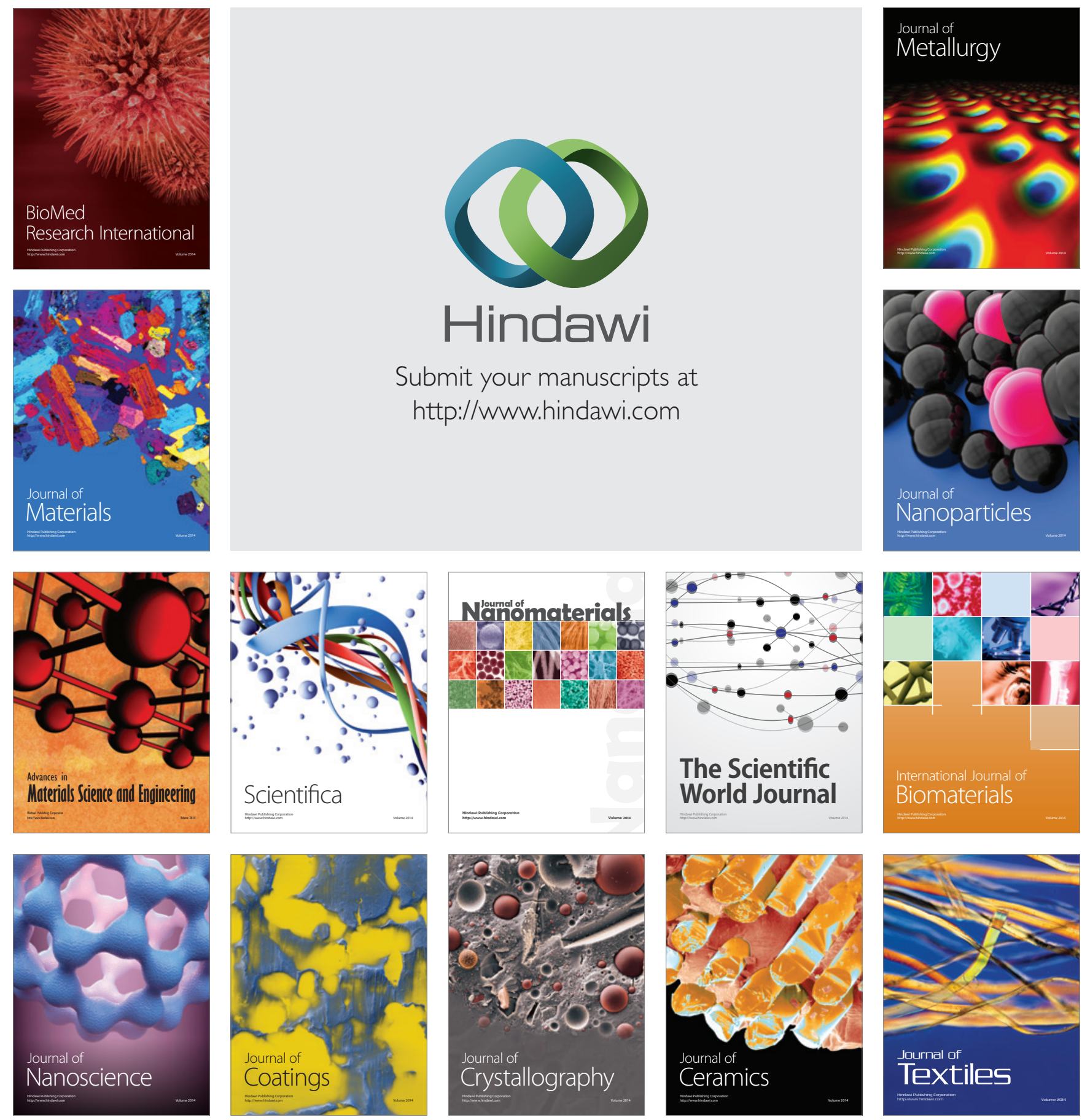